\title{
Theocritus, Calvus, and Eclogue 6
}

\section{Citation}

Thomas, Richard F. 1979. Theocritus, Calvus, and Eclogue 6. Classical Philology 74(4): 337-339.

\section{Published Version}

doi:10.1086/366521

\section{Permanent link}

http://nrs.harvard.edu/urn-3:HUL.InstRepos:3746878

\section{Terms of Use}

This article was downloaded from Harvard University's DASH repository, and is made available under the terms and conditions applicable to Other Posted Material, as set forth at http:// nrs.harvard.edu/urn-3:HUL.InstRepos:dash.current.terms-of-use\#LAA

\section{Share Your Story}

The Harvard community has made this article openly available.

Please share how this access benefits you. Submit a story.

\section{Accessibility}




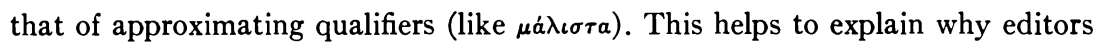
and lexicographers have often had trouble in elucidating its meaning and use in particular passages. ${ }^{27}$

Catherine Reid Rubincam

Erindale College

University of Toronto

27. This paper was written with the support of a Canada Council Leave Fellowship. I am grateful to Joan Bigwood for reading and commenting on an earlier version of this paper, and to the journal's referees for some useful suggestions toward improving the argument.

\section{THEOCRITUS, CALVUS, AND ECLOGUE 6}

Of the six unconnected lines surviving from Calvus' epyllion, none is better known than the neoteric exclamation addressed to Io herself (Serv. Dan. ad Ecl. 6. $47=$ Calvus frag. 9 Morel):

a virgo infelix, herbis pasceris amaris.

We are indebted to Servius Danielis; for, as has been noted, ${ }^{1}$ it can be seen that in Eclogue 6 Virgil drew from Calvus' line to produce an acknowledgment of previous literary expression. Stewart observes that at Eclogue 6. 47 ("a, virgo infelix, quae te dementia cepit!") Virgil combined the first half of Calvus' line with the second half of a verse from Eclogue 2 (69 "a Corydon, Corydon, quae te dementia

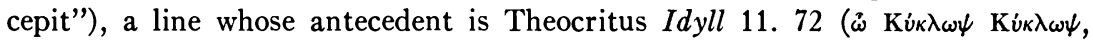

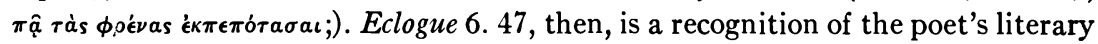
predecessors, molded into a single Virgilian line.

But what of line 52 of the same poem?

a! virgo infelix, tu nunc in montibus erras.

Virgil does not lightly repeat himself, and we may ask why this line, with the alteration of the second half, reappears after five verses. It is true that there is a structural purpose to the repetition: lines 47-52 are, in fact, a self-contained panel. ${ }^{2}$ But why the c'lange in the second half ("tu nunc in montibus erras")? The motif of wandering is common in the Eclogues, particularly in Eclogue $6 .{ }^{3}$ For the moment, however, instances outside this poem will be important. First, Eclogue 2. 21:

mille meae Siculis errant in montibus agnae.

As Servius recognized, Virgil drew from, but altered, Theocritus (again the Cyclops poem) at this point:

1. Z. Stewart, "The Song of Silenus," HSCP 64 (1959): 190.

2. Briefly noted, together with other panels, by F. Skutsch, A us Vergils Frïhzeit (Leipzig, 1901), p. 13.

3. J. P. Elder, "Non Iniussa Cano," HSCP 65 (1961): 118-19, points to the numerous instances of erra- in the Eclogues, particularly $6.40,52,58$, and 64 . Is there significance in the distribution -an interval of twelve lines followed by two of six? 


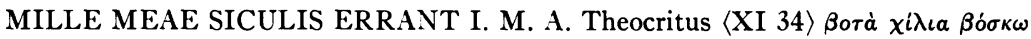
errant autem cum securitate pascuntur.

Again, on Eclogue 1. 9-10:

ERRANT pasci ut $\langle$ II 21 $\rangle$ mille meae Siculis errant in montibus agnae.

The discrepancy in verbs between Theocritus and Virgil seemed significant to Servius, as it should to us, for Virgil clearly had Idyll 11 constantly before him while writing Eclogue 2. When he wrote errant, he intended his reader to recall the Theocritean verse and to supply pascuntur. Nor is Servius alone in seeing this approximation. Pseudo-Acron, on Horace Epode 2. 12 ("prospectat errantis greges"), notes:

ERRANTES GREGES libere pascentes ut $\langle$ Virg. Ecl. 1. 9〉 ille meas errare boves.

Thus, Virgil creates a parallel between grazing and wandering: errare and pasci can imply the same activity.

Let us return to Eclogue 6. When Virgil repeated Calvus' exclamation at line 52, but ended the line differently ("tu nunc in montibus erras"), he intended his reader to consider the model again, this time, however, the second half of Calvus' line as well as the first:

a virgo infelix, herbis pasceris amaris.

Keeping in mind the equivalent meaning possible for pasci and errare (as established at $E c l$. 2. 21), we will see exactly what Eclogue 6. 52, seemingly anticlimactic after its allusive counterpart five lines earlier, represents: a restatement, in Virgilian terms, of the complete line of Calvus - in this context, pasceris and erras are virtually interchangeable. Pasiphae's actions, then, are those of Io. Virgil, it seems, gives an additional indication of his source by alluding, two lines later (in the same metrical position, and in the same word order - verb enclosed by noun and adjective), to Calvus' half line ("pallentis ruminat herbas").

In the poetic genealogy of Eclogue 6 Virgil appears to have played further on this connection. He makes Linus the shepherd ( 67 pastor $)^{4}$ hand the pipes of Hesiod to Gallus, who is wandering (64 errantem) on the banks of the Permessus. Of course, errare here has only its conventional sense; but, since the verb is applied to Linus as pastor, its appearance does seem significant when we consider Virgil's earlier approximation of errare to pasci.

This leads to other considerations. Pasci obviously has a central place in pastoral poetry. Wandering, as noted, is also a prominent feature of the Eclogues. In particular, it can be the activity of the elegiac lover. In Eclogue 6 Virgil had placed Gallus, the author of the Amores, in this situation, just as Propertius, in the first poem of the Monobiblos, was to describe (the Gallan) Milanion, stricken by love:

4. Virgil elsewhere shows an interest in words derived from pasco: Ecl. 6. 4-5 "pastorem, Tityre, pinguis / pascere oportet ovis," G. 2. 435-36 "pastoribus . . pabula," G. 3. 339-42 "pastores ... pascua ... pascitur." For an elaborate development of this feature of Virgilian poetry, together with further etymological allusion, see David O. Ross, Jr., Backgrounds to Augustan Poetry (Cambridge, 1975), pp. 155-56 (on Tib. 2. 5. 25-30). Ross (pp. 21-23) also discusses the significance of Linus' role as pastor. 
"nam modo Partheniis amens errabat in antris" (1. 1. 11). So Virgil makes Pasiphae, who is subject to frustrated love, wander in the mountains. Errare is thus appropriate in this sense at Eclogue 6. 52, as well as in the sense established in Eclogue 2.

We can go no farther, for without the poetry of Calvus and Gallus the full significance of Virgil's construct is lost. If, from a single line, it is possible to detect Virgil's reshaping of his poetic antecedents, we can only regret once again the loss of those earlier works.

RichaRd F. Thomas Harvard Lniversity

5. Cf. H. Tränkle, Die Sprachkunst des Properz und die Tradition der lateinischen Dichtersprache, Hermes Einzelschriften, 15 (Wiesbaden, 1960), p. 13, for the tradition of amens errabat, and Ross, Backgrounds, pp. 61-64, for the demonstration that this phrase, together with the entire Milanion exemplum, reflects a Gallan archetype. 